\title{
Improving Strawberry Irrigation with Micro-Sprinklers and Their Impact on Pest Management
}

\author{
Surendra K. Dara ${ }^{1}$, Samuel Sandoval-Solis ${ }^{1,2}$, David Peck ${ }^{3}$ \\ ${ }^{1}$ University of California Cooperative Extension, San Luis Obispo, CA, USA \\ ${ }^{2}$ Department of Land, Air and Water Resources, Davis, CA, USA \\ ${ }^{3}$ Manzanita Berry Farms, Santa Maria, CA, USA \\ Email: *skdara@ucdavis.edu
}

How to cite this paper: Dara, S.K., Sandoval-Solis, S. and Peck, D. (2016) Improving Strawberry Irrigation with Micro-Sprinklers and Their Impact on Pest Management. $A g$ ricultural Sciences, 7, 859-868.

http://dx.doi.org/10.4236/as.2016.712078

Received: September 10, 2016

Accepted: December 20, 2016

Published: December 23, 2016

Copyright (c) 2016 by authors and Scientific Research Publishing Inc. This work is licensed under the Creative Commons Attribution International License (CC BY 4.0).

http://creativecommons.org/licenses/by/4.0/

\begin{abstract}
Overhead aluminum sprinklers, which are used during the early stages of strawberry crop development to establish transplants and to leach out salts from the root zone, deliver significant volumes of water. Micro-sprinklers, which are typically used in orchard crops, were evaluated in a commercial strawberry field in California as an alternative to conventional aluminum sprinklers to conserve water without any negative impact on yields. In addition to the water consumption, data were collected from multiple plots within each treatment to determine the impact on plant growth, disease incidence, and seasonal yield. Micro-sprinklers used 32\% less water than aluminum sprinklers during a three-week period without affecting fruit yield. They also appeared to lessen the severity of powdery mildew and botrytis fruit rot. This is the first study reporting the use of micro-sprinkler system, which can be a good alternative to the aluminum sprinklers to conserve irrigation water.
\end{abstract}

\section{Keywords}

Strawberry, Irrigation, Micro-Sprinkler, Powdery Mildew, Botrytis Fruit Rot

\section{Introduction}

Strawberry is an important commercial crop in California and primarily grown in the Watsonville, Santa Maria, and Oxnard production areas in the Central Coast on about 37,000 acres annually [1]. It is the fifth most important commodity in California with a crop value of $\$ 2.5$ billion and California produces $90 \%$ of fresh market and $96 \%$ processing strawberries in the United States [2]. 
Strawberry crop requires about 2 acre-feet of irrigation water during a typical production season for fall planting. Fall planting typically starts in October-November and ends in July-August of the following year. Evapotranspiration of strawberry crop varies depending on the micro-climate of the production region, seasonal climatic variations, type of irrigation system used, and general agronomic practices. For example, a twoyear study conducted in 2009 and 2011 in the Monterey Bay area showed that the average evapotranspiration varied between 2 and 2.5 acre-feet [3].

Strawberries are mainly irrigated through a drip system where drip tapes are installed under plastic mulch when beds are prepared. Drip irrigation is supplemented with overhead aluminum sprinkler irrigation during the first few weeks after transplanting to leach out salts from the root zone and to help with transplant establishment. Strawberry crop is sensitive to salinity and overhead aluminum sprinkler irrigation reduces and prevents salt injury [4]. Aluminum sprinklers are also considered very important in the Oxnard area to prevent dry conditions from Santa Ana winds during the early stages of crop establishment. However, supplemental irrigation with these aluminum sprinklers requires a significant amount of water and can be less efficient than other irrigation systems [5]. Some disadvantages of the aluminum sprinklers include increased evaporation, excessive water delivery than what can penetrate into the beds through the openings on the plastic mulch, and potential runoff if managed improperly.

Application efficiency (AE refers to the efficiency of an irrigation system in delivering a specific amount of water) studies showed that micro-sprinklers are more efficient (81\% AE) than hand-move sprinkler systems $(70 \% \mathrm{AE})$ [5]. Water is an important resource in crop production and improved irrigation practices are a critical need in a high value crop like strawberry, especially under the current drought conditions in California. Micro-sprinklers, which are commonly used in orchard systems, could be an efficient alternative to aluminum sprinklers. Installed on strawberry beds, microsprinklers can deliver water in a more controlled and targeted manner with minimum or no runoff. Additionally, micro-sprinklers could also contribute to improved humidity in the strawberry microclimate, which discourages twospotted spider mite populations and promotes predatory mites that are sensitive to hot and dry conditions. High humidity in the microclimate is beneficial to entomopathogenic fungi such as Beauveria bassiana, which are applied as biopesticides for controlling twospotted spider mite and insect pests [6] [7]. Some growers have indicated using micro-sprinklers in organically produced strawberries as a means of controlling twospotted spider mites, but there are no data available on its impact.

A study was conducted in Santa Maria during the 2014-2015 production season to assess the potential of micro-sprinklers as an alternative to overhead aluminum sprinklers. Specific objectives of this study included: 1) if micro-sprinklers conserve water without a negative impact on strawberry plant growth and fruit yield; 2) if microsprinklers have any impact on pest and predatory mite populations; and 3) if microsprinklers have any impact on powdery mildew and botrytis fruit rot. 


\section{Materials and Methods}

This study was conducted at Manzanita Berry Farms in Santa Maria on a conventional strawberry field with variety BG-6.3024 planted on 6 November, 2014. A strawberry block with about 135 beds aligned in a north-south direction was divided into two sections. The west half of the block was assigned for the micro-sprinklers and the east half for aluminum sprinklers, which was the grower standard (Figure 1). The length of the beds varied from 306' at the east end to 365' at the west end. Within each section of the treatment, 20' long plots were marked on six random beds as sample plots to measure plant, pest, and disease parameters. Data were collected periodically and analyzed using

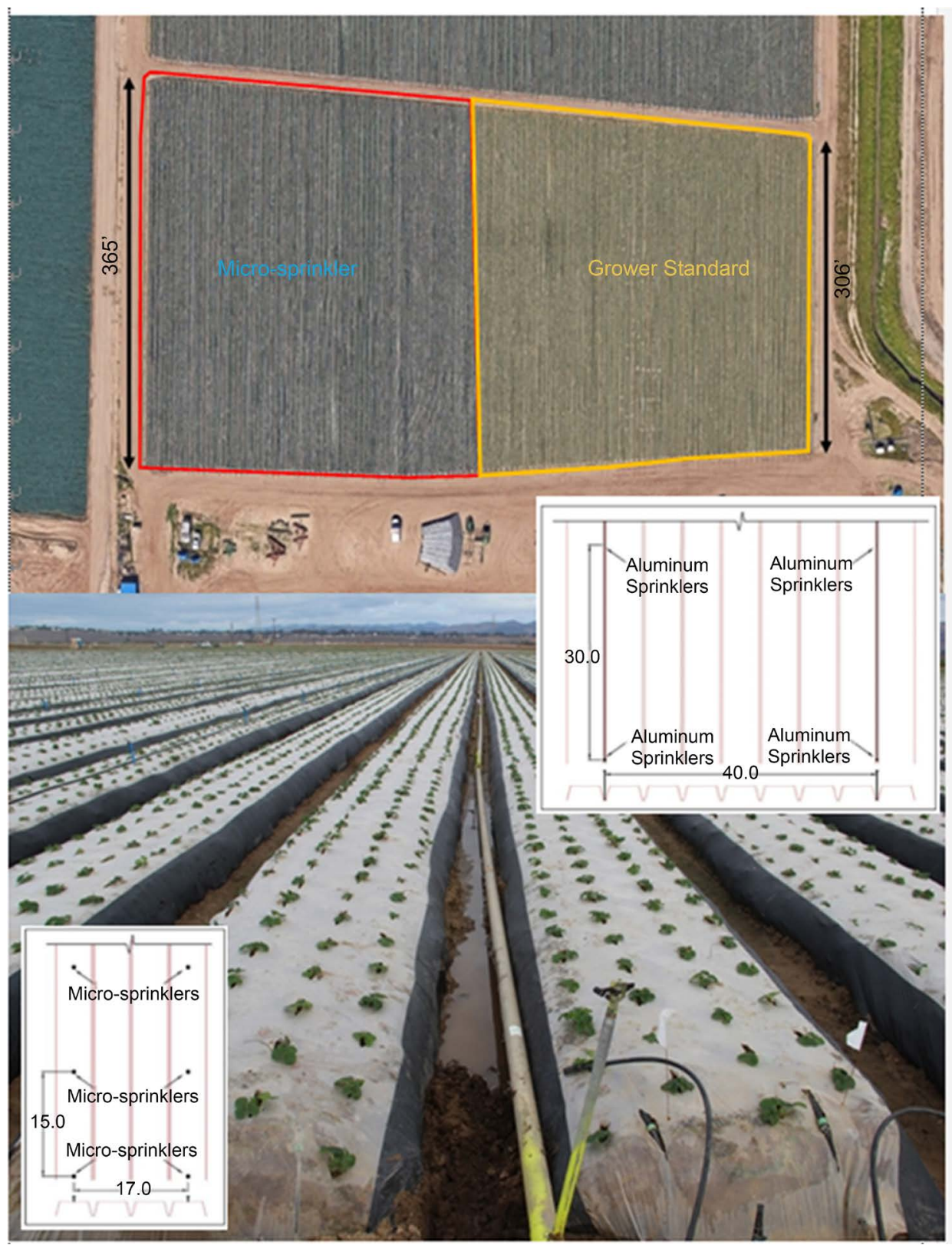

Figure 1. Experimental plots and configuration of micro-sprinklers and aluminum sprinklers. 
ANOVA. Significant means were separated using Tukey's HSD test.

\subsection{Irrigation Management}

Micro-sprinklers were installed on every fourth bed (about 16' apart) and had a 15' spacing between two sprinkler heads within a bed. Aluminum sprinklers were installed in furrows every $40^{\prime}$ with 7 - 8 beds in between. Sprinkler heads were spaced 30' apart on each pipe. Supplemental irrigation during the transplant establishment period was administered from 6 to 29 November, 2014. During this period, there were 14 irrigation events using aluminum sprinklers where 125 gallons of water was delivered per minute. Micro-sprinklers were used each time for 2 hours at 1 - 3 day intervals where 40 gallons per minute were delivered at 35 PSI pressure.

\subsection{Crop Yield}

Plots were marked with flags and covered with netting to prevent accidental harvesting by the commercial harvesting crew. Total and marketable strawberry yield data were collected 2 to 3 times every week, following the normal harvest schedule, between 7 February and 12 June, 2015 for a total of 34 sampling dates.

\subsection{Plant Canopy and Health}

Plant growth was recorded by measuring the width of the plant canopy across and along the length of the bed from 20 random plants within each plot on the 6th day of each month from January to March, 2015. Plant health was monitored at the same time on a scale of 0 to 5 where $0=$ dead, $1=$ weak, $2=$ moderate-low, $3=$ moderate-high, $4=$ good, and 5 = very good.

\subsection{Twospotted Spider Mite and Predatory Mites}

One mid-tier leaflet from each of the 10 random plants within each plot was sampled once a month from February to April, 2015. The number of eggs, nymphs, and adult stages of both pest and predatory mites were counted using a mite brushing machine.

\subsection{Powdery Mildew}

One trifoliate leaf from each of the 20 random plants within each plot were collected on 14 April and 16 and 24 June, 2015. Leaves were examined under a microscope for mycelial growth and powdery mildew severity was recorded on a scale of 0 to 4 where $0=$ absent, $1=1 \%-25 \%, 2=26 \%-50 \%, 3=51 \%-75 \%$, and $4=76 \%-100 \%$ of leaf area with infection.

\subsection{Botrytis Fruit Rot}

Strawberries harvested from each plot on 26 March, 13 April, 22 May, and 16 June, 2015, were kept at room temperature in plastic clamshell boxes. Disease severity was measured 3 and 5 days after harvest based on mold growth on the same scale used for powdery mildew. 


\section{Results and Discussion}

\subsection{Irrigation Management}

During this period, aluminum sprinklers delivered 120,000 gallons of water over 16 hours of irrigation whereas micro-sprinklers delivered 81,600 gallons over 34 hours (Figure 2). This translates to 38,400 gallons or $32 \%$ of water savings in just three weeks for micro-sprinklers. Considering extended periods of overhead irrigation in other field situations, water savings could be significantly higher from micro-sprinklers.

Micro-sprinkler irrigation events were continued twice a week, 15 min each time, after 29 November for the rest of the production season to discourage twospotted spider mite populations. Distribution uniformity (DU) for the micro-sprinkler system was $74 \%$ at 35 PSI when measured on 16 January, 2015. DU could not be measured for aluminum sprinklers, but it is believed to be between $50 \%-60 \%$ at 70 PSI [5]. Electrical conductivity (EC) was measured for both irrigation systems on 1 January and 1 February, 2015. EC value for micro-sprinklers was $0.54 \mathrm{dS} / \mathrm{m}$, but it varied between 0.47 and $0.49 \mathrm{dS} / \mathrm{m}$ for aluminum sprinklers. Although the EC value in micro-sprinkler plots was significantly higher $(P<0.0007)$ than in the aluminum sprinkler plots, it was below the recommended limit of $0.7 \mathrm{dS} / \mathrm{m}[8]$.

\subsection{Crop Yield}

When seasonal average was considered, there was no significant difference $(P>0.05)$ between the yield of marketable berries in micro-sprinkler and aluminum sprinkler plots (Figure 3). A total of 43,452 gr (95.8 lb) of marketable strawberries were produced per plot in micro-sprinkler treatment and 44,322 $\mathrm{gr}(97.7 \mathrm{lb})$ in the aluminum sprinkler treatment (Figure 4).

\subsection{Plant Canopy and Health}

Plants in the micro-sprinkler plots had significantly smaller canopy in January $(P=0.004)$

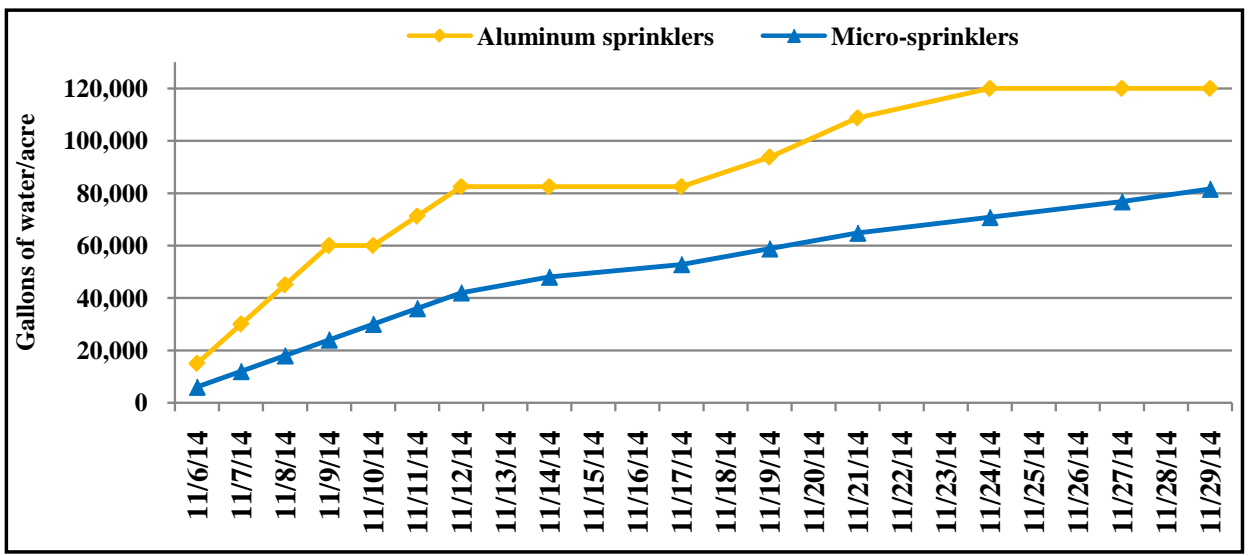

Figure 2. Cumulative irrigation volume delivered by aluminum and micro-sprinkler systems from 6 to 29 November, 2014. 


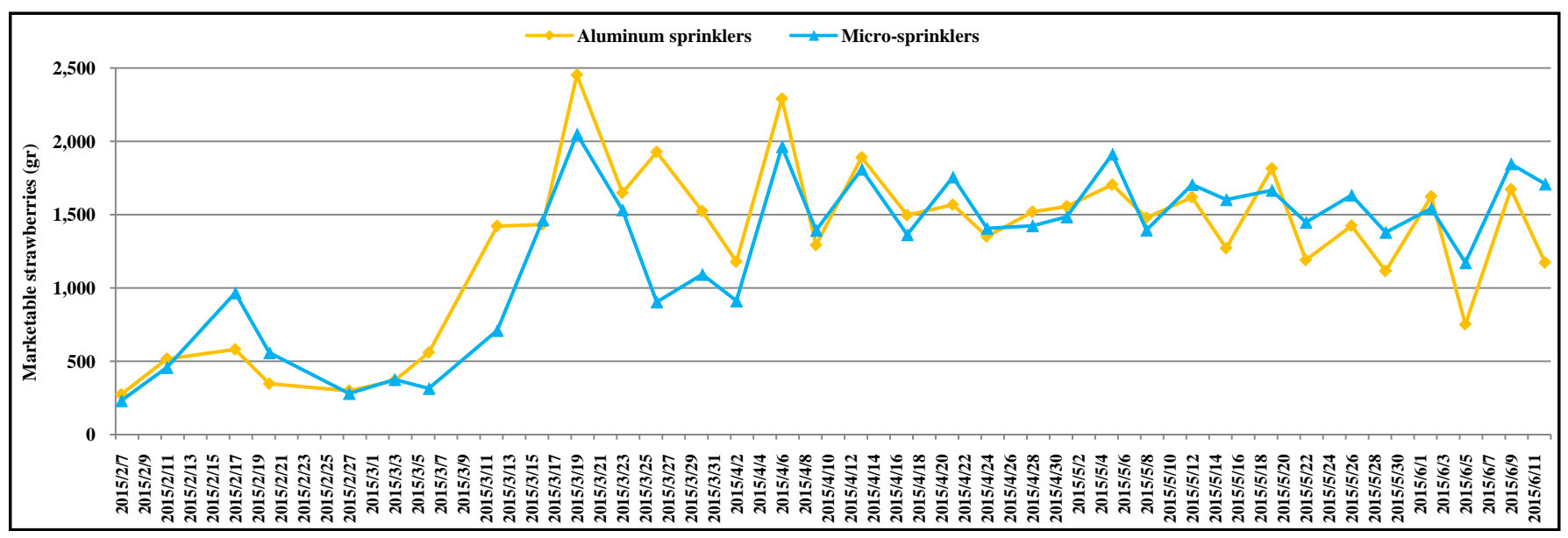

Figure 3. Cumulative marketable strawberry yields at each harvest from aluminum and micro-sprinkler plots.

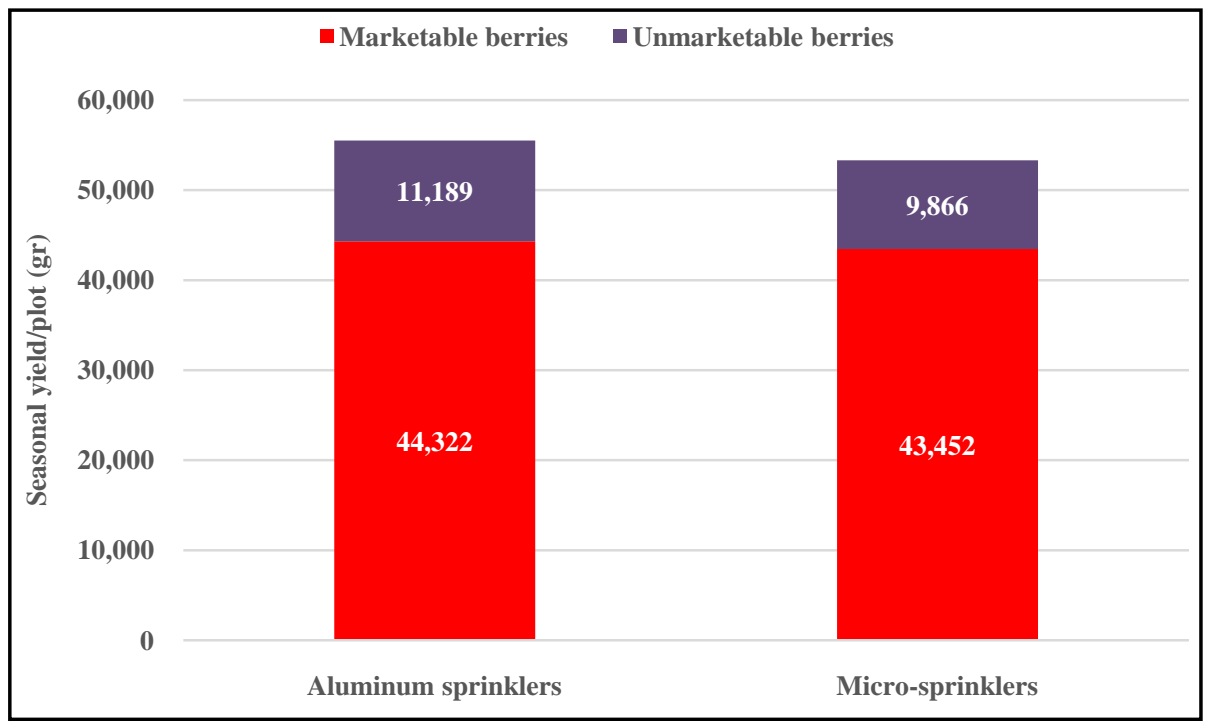

Figure 4. Seasonal totals for marketable and unmarketable strawberries from aluminum and micro-sprinkler plots.

and February $(P=0.0006)$, but caught up with the plants in the aluminum sprinkler plots by March $(P=0.14)$ (Figure 5$)$. Plant health rating also followed a similar trend during this period, but significant differences were seen only in February $(P=0.02)$ (Figure 6).

\subsection{Twspotted Spider Mite and Predatory Mites}

Due to sparse numbers and uneven distribution of mites, comprehensive data could not be collected.

\subsection{Powdery Mildew}

Powdery mildew severity was significantly less in micro-sprinkler treatment on 15 April $(P=0.009)$ and June $24(P=0.01)$ (Figure 7$)$. 


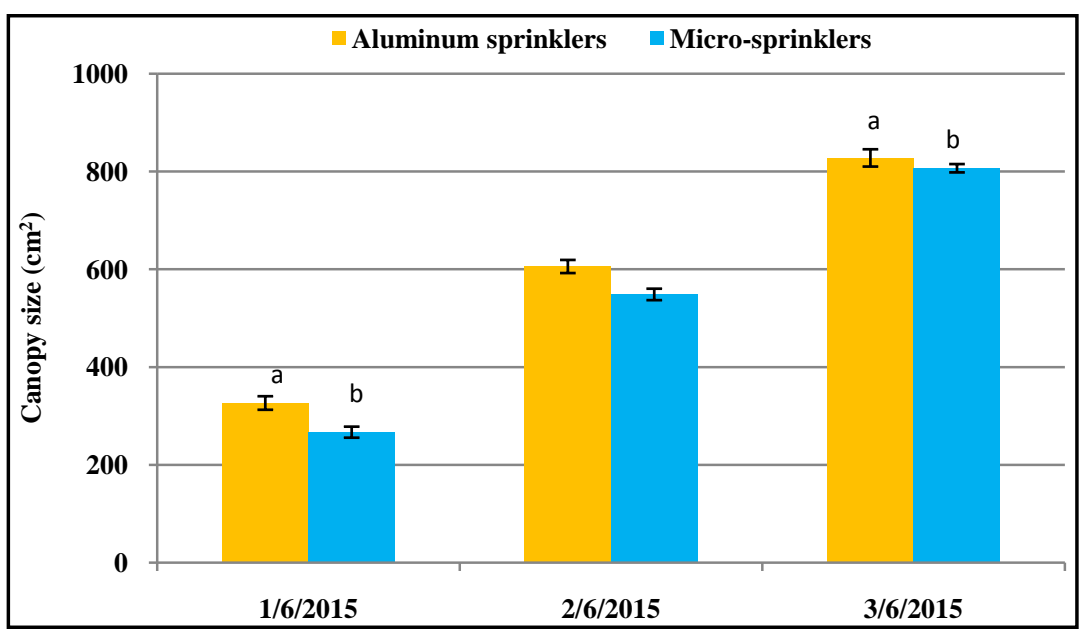

Figure 5. Strawberry plant growth, expressed as canopy size, in aluminum and micro-sprinkler plots.

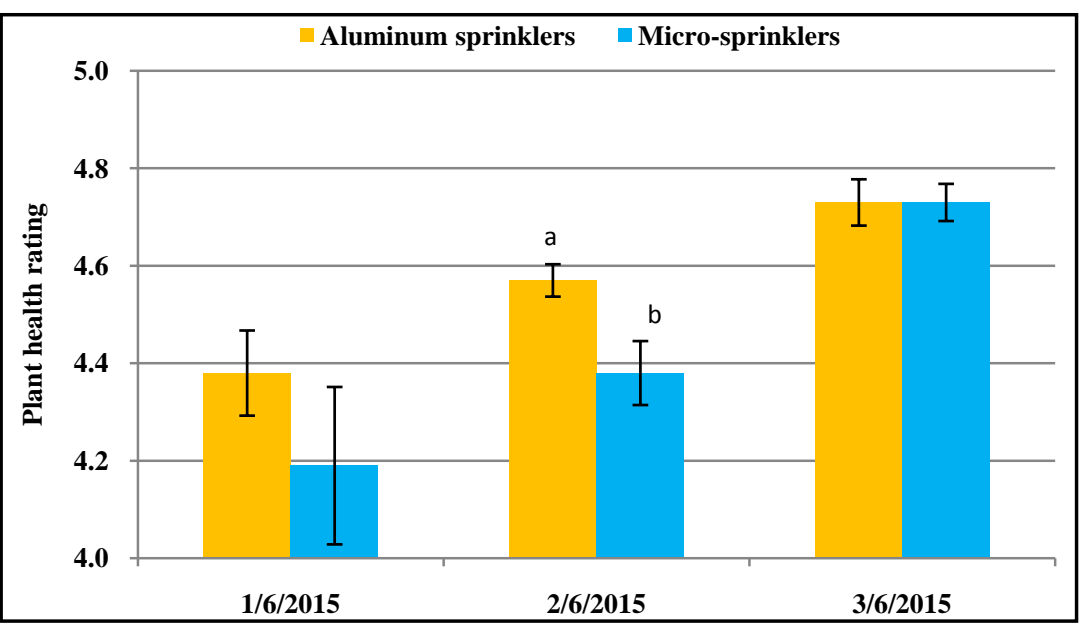

Figure 6. Health of the strawberry plants in aluminum and micro-sprinkler plots.

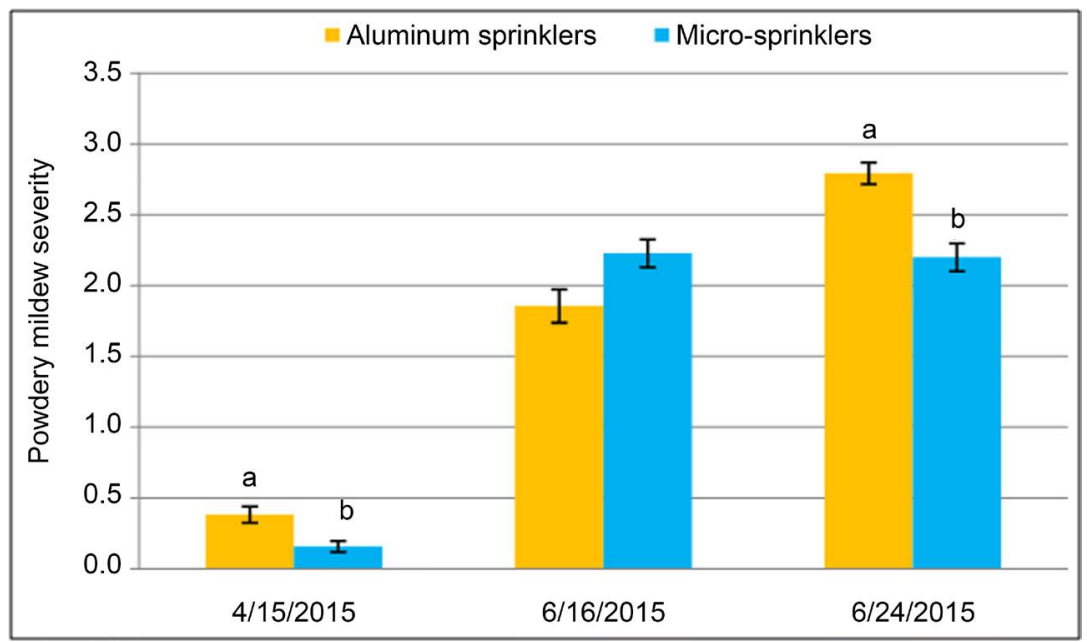

Figure 7. Severity of powdery mildew in aluminum and micro-sprinkler plots. 


\subsection{Botrytis Fruit Rot}

Micro-sprinkler plots appeared to have a lower level of botrytis fruit rot, but significant differences were seen only 3 days after harvest for strawberries sampled on 22 May and 16 June $(P=0.02)$ (Figure 8$)$.

The micro-sprinkler system contributed to a significant reduction in supplemental overhead irrigation water without adversely affecting the marketable strawberry yield. Since less pressure is required for micro-sprinklers than aluminum sprinklers to deliver

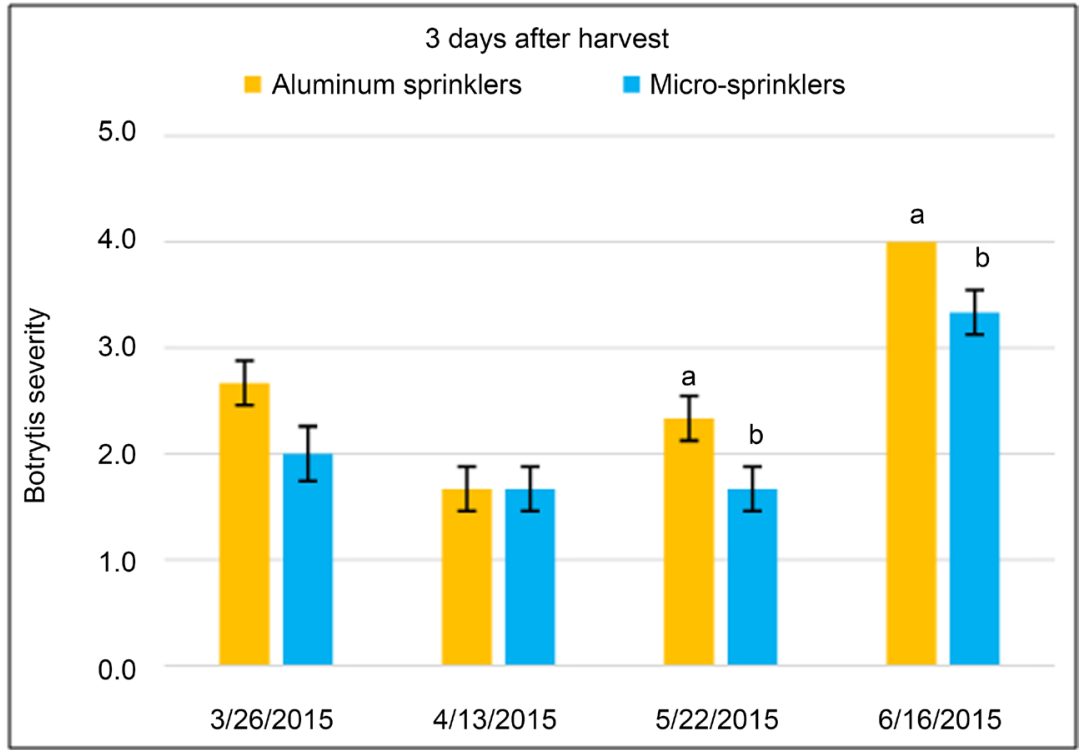

(a)

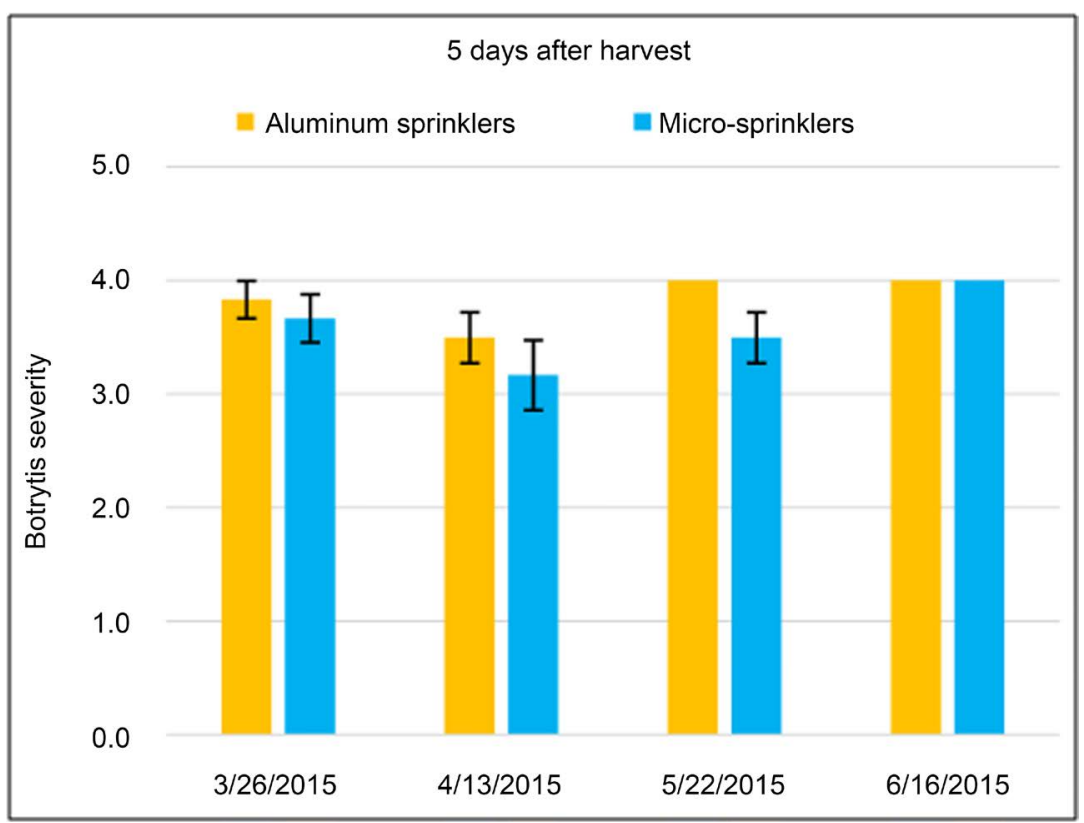

(b)

Figure 8. Severity of botrytis fruit rot 3 (a) and 5 (b) days after harvest in aluminum and microsprinkler plots. 
water, energy savings and less carbon emissions are also possible from the microsprinkler system. EC value below the recommended level $(0.07 \mathrm{dS} / \mathrm{m})$ also suggests that micro-sprinklers were as effective as aluminum sprinklers in leaching out salts from the root zone without excessive water use. Although data on mite populations were insufficient to draw valid conclusions, it should be noted that micro-sprinklers are considered by some growers to assist with twospotted spider mite control throughout the production season. Data also suggest that micro-sprinklers have a positive impact on reducing powdery mildew and botrytis fruit rot.

Micro-sprinkler irrigation over trees improved the color and anthocyanin of apples in a study conducted in Spain [9]. A Polish study in raspberry compared drip and micro-sprinkler irrigation systems to no irrigation [10]. Although not significantly different from drip-irrigated plots, plant height, marketable yields, and berry weight were the highest in micro-sprinkler-irrigated plots. Interestingly, the carotene and vitamin A contents were the highest in unirrigated plots followed by micro-sprinkler, and drip-irrigated plots. Other studies where micro-sprinklers were used in almond in California [11], onion in India [12], and mango in Brazil [13] evaluated the application efficiency, influence of the depth of irrigation, and methods of interpreting field measurements of energy fluxes, respectively, but none of them compared micro-sprinklers with conventional irrigation systems. This is the first study in strawberries comparing conventional overhead aluminum sprinklers to micro-sprinklers. This study demonstrated that micro-sprinklers can contribute to a significant reduction in supplemental irrigation water in strawberry production while having a positive impact on disease control. Additional experiments are necessary to strengthen the trends observed in this study and to refine irrigation schedules.

\section{Acknowledgements}

Thanks to Manzanita Berry Farms' field crew, Chris Martinez, and Fritz Light for their technical assistance and Netafim and RDO Water for their financial support.

\section{References}

[1] California Strawberry Commission (CSC) (2015) 2015 Acreage Survey. http://reports.calstrawberry.org/Reports/Acreage\%20Survey/2015\%20Acreage\%20Survey.p df

[2] California Department of Food and Agriculture (CDFA) (2015) California Agricultural Statistics Review, 2014-2015. https://www.cdfa.ca.gov/statistics/PDFs/2015Report.pdf

[3] Lin, V., Sandoval-Solis, S., Lane, B.A. and Rodriguez, J.M. (2013) Potential Water Savings through Improved Irrigation Efficiency in Pajaro Valley, California. Final Report, Water Management Research Group, University of California Davis, Davis.

[4] Dara, S.K. (2012) Salt Injury in Strawberries. UCCE eNewsletter Strawberries and Vegetables. http://ucanr.edu/blogs/blogcore/postdetail.cfm?postnum $=6820$

[5] Sandoval-Solis, S., Orang, M., Snyder, R.L., Orloff, S., Williams, K.E. and Rodriguez, J.M. (2013) Spatial Analysis of Application Efficiencies in Irrigation for the State of California. Final Report, Water Management Research Group, University of California Davis, Davis. 
[6] Shipp, J.L., Zhang, Y., Hunt, D.W.A. and Ferguson, G. (2003) Influence of Humidity and Greenhouse Microclimate on the Efficacy of Beauveria bassiana (Balsamo) for Control of Greenhouse Arthropod Pests. Environmental Entomology, 32, 1154-1163.

https://doi.org/10.1603/0046-225X-32.5.1154

[7] Dara, S.K. (2016) Managing Strawberry Pests with Chemical Pesticides and Non-Chemical Alternatives. International Journal of Fruit Science, 16, 1-13.

https://doi.org/10.1080/15538362.2016.1195311

[8] Strand, L.L. (2008) Integrated Pest Management for Strawberries. 2nd Edition, UC ANR Publication 3351, Oakland.

[9] Iglesias, I., Salvia, J., Torguet, L. and Cabús, C. (2002) Orchard Cooling with Overtree Microsprinkler Irrigation to Improve Fruit Colour and Quality of “Topred Delicious” Apples. Scientia Horticulturae, 93, 39-51. https://doi.org/10.1016/S0304-4238(01)00308-9

[10] Rolbiecki, S., Rolbiecki, R. and Rzekanowski, C. (2002) Effect of Micro-Irrigation on the Growth and Yield of Raspberry (Rubus idaeus L.) cv. "Polana" Grown in Very Light Soil. Acta Horticulturae, 585, 653-657. https://doi.org/10.17660/actahortic.2002.585.108

[11] Koumanov, K.S., Hopmans, J.W., Schwankl, L.J., Andreu, L. and Tuli, A. (1997) Application Efficiency of Micro-Sprinkler Irrigation of Almond Trees. Agricultural Water Management, 34, 247-263. https://doi.org/10.1016/S0378-3774(97)00030-9

[12] Sarkar, S., Goswami, S.B., Mallick, S. and Nanda, M.K. (2008) Different Indices to Characterize Water Use Pattern of Micro-Sprinkler Irrigated Onion (Allium cepa L.). Agricultural Water Management, 95, 625-632. https://doi.org/10.1016/j.agwat.2008.01.002

[13] Teixeira, A.H.C. and Bastiaanssen, W.G.M. (2012) Five Methods to Interpret Field Measurements of Energy Fluxes over a Micro-Sprinkler-Irrigated Mango Orchard. Irrigation Science, 30, 13-28. https://doi.org/10.1007/s00271-010-0256-y

Submit or recommend next manuscript to SCIRP and we will provide best service for you:

Accepting pre-submission inquiries through Email, Facebook, LinkedIn, Twitter, etc.

A wide selection of journals (inclusive of 9 subjects, more than 200 journals)

Providing 24-hour high-quality service

User-friendly online submission system

Fair and swift peer-review system

Efficient typesetting and proofreading procedure

Display of the result of downloads and visits, as well as the number of cited articles

Maximum dissemination of your research work

Submit your manuscript at: http://papersubmission.scirp.org/

Or contact as@scirp.org 